\title{
Determinan Tingkat Pendapatan Nelayan Perahu Motor Tempel Jurnal Ecces
}

\author{
Wardihan Sabar ${ }^{1}$, \\ Nur Indasari ${ }^{2}$
}

1,2Program Studi Ilmu Ekonomi

Fakultas Ekonomi Dan Bisnis Islam Universitas Islam Negeri Makassar

Jl. Yasin Limpo, No. 36 Samata, GowaSulawesi Selatan

E-mail : wardihan.sabar@gmail.com ${ }^{1}$, indah.study@gmail.com ${ }^{2}$

\section{Abstrak:Determinan Tingkat Pendapatan Nelayan Perahu Motor Tempel}

Kabupaten Takalar sebagai salah satu sentrum produksiperikanan tangkap di Sulawesi Selatan, mengalami peningkatan produksi dari waktu ke waktu. Akan tetapi, kondisi tersebut justru belum mampu meningkatkan pendapatan nelayan secara signifikan di wilayah ini. Hal tersebut semakin diperparah dengan rendahnya tingkat produktifitas nelayan, sehingga masalah ini kian begitu kompleks secara keseluruhan di Kabupaten Takalar, termasuk yang ada di Desa Tamasaju Kecamatan Galesong Utara Kabupaten Takalar.Penelitian ini bertujuan untuk untuk menganalisis faktor-faktor yang mempengaruhi pendapatan nelayan perahu motor tempel di Desa Tamasaju Kecamatan Galesong Utara Kabupaten Takalar. Penelitian ini merupakan penelitian kuantitatif, dengan pendekatan eksplanatori. Data yang digunakan adalah data primer yang diperoleh dengan teknik kuesioner. Analisis data dilakukan melalui teknik regresi linear berganda dengan pendekatan fungsi Cobb-Douglas, dan pengujian Asumsi Klasik. Data diolah dengan menggunakan program SPSS 23. Hasil penelitian menunjukkan bahwa variabel biaya bahan bakar minyak berpengaruh positif dan signifikan terhadap pendapatan nelayan perahu motor tempel di Desa Tamasaju, pengalaman melaut berpengaruh positif namun tidak signifikan, sedangkan lama melaut dan umur nelayan berpengaruh negatif dan tidak signifikan terhadap pendapatan nelayan perahu motor tempel di Desa Tamasaju. Dengan demikian hasil penelitian ini diharapkan dapat bermanfaat dalam menyusun kebijakan dan strategi untuk meningkatkan pendapatan nelayan perahu motor tempel di Desa Tamasaju Kecamatan Galesong Utara Kabupaten Takalar.

Kata Kunci: Determinan Pendapatan, Nelayan, Perahu Motor. 


\section{Abstract: Determinant Of Income Level of Outboard Motor Boat Fisherman}

Takalar Regency as one of the centers of capture fisheries production in South Sulawesi, has increased production from time to time. However, these conditions have not been able to increase fishermen's income significantly in this region. This is further exacerbated by the low level of productivity of fishermen, so the problem is increasingly so complex as a whole in Takalar District, including those in Tamasaju Village, North Galesong District, Takalar.This study aims to analyze the factors affecting the fishing village in Tamasaju Village District North Galesong TaSSSkalar District. This research is a quantitative research, using explanatory. The data used are primary data obtained by questionnaire technique. Data analysis was done by multiple linear regression technique with Cobb-Douglas function approach, and Classic Assumption test. Data was processed by using SPSS program 23. The results showed that the variable cost of fuel oil has a positive and significant effect on the income of outboard fishermen in Tamasaju Village, the experience of sea fishing has a positive but insignificant effect, while the old fishing and the age of the fisherman negative and insignificant fishing village outboard motor in Tamasaju Village. Thus the results of this study can be used to increase the income of fishermen in the village Tamasaju North Galesong District Takalar District.

Keywords: Determinant Income, Fisherman, Motor Boat.

\section{PENDAHULUAN / INTRODUCTION}

Kabupaten Takalar sebagai salah satu sentrum produksiperikanan tangkap di Sulawesi Selatan, mengalami peningkatanproduksi dari waktu ke waktu. Akan tetapi, kondisi tersebut justru belum mampu meningkatkan pendapatan nelayan secara signifikan di wilayah ini. Hal tersebut semakin diperparah dengan rendahnya tingkat produktifitas nelayan, sehingga masalah ini kian begitu kompleks secara keseluruhan di Kabupaten Takalar, termasuk yang ada di Desa Tamasaju Kecamatan Galesong Utara Kabupaten Takalar.

Perikanan merupakan salah satu bidang yang diharapkan mampu menjadi penopang peningkatan kesejahteraan rakyat Indonesia. Subsektor perikanan dapat berperan dalam pemulihan dan pertumbuhan perekonomian bangsa Indonesia karena potensi sumberdaya ikan yang besar dalam jumlah dan keragamannya (Jehau, 2009).Sumber daya perikanan sebenarnya secara potensial dapat di manfaatkan untuk meningkatkan taraf hidup dan kesejahteraan nelayan, namun pada kenyataannya masih cukup banyak nelayan belum dapat meningkatkan hasil tagkapannya, sehingga tingkat pendapatan nelayan tidak meningkat.

Masyarakat nelayan adalah masyarakat yang hidup, tumbuh, dan berkembang di kawasan pesisir, yakni suatu kawasan transisi antara wilayah darat dan laut. Sebagai suatu sistem, masyarakat nelayan terdiri atas kategori-kategori sosial yang membentuk kesatuan 
sosial. Mereka juga memiliki sistem nilai dan simbol-simbol kebudayaan sebagai referensi perilaku mereka sehari-hari. Faktor kebudayaan ini menjadi pembeda masyarakat nelayan dari kelompok sosial lainnya. Sebagian masyarakat pesisir, baik masalah politik, sosial, dan ekonomi yang kompleks.

Masalah-masalah tersebut diantaranya sebagai berikut: (1) kemiskinan, kesenjangan sosial, dan tekanan-tekanan ekonomi yang datang setiap saat, (2) keterbatasan akses modal, tekhnologi, dan pasar, sehingga mempengaruhi dinamika usaha, (3) kelemahan fungsi kelembagaan sosial ekonomi yang ada, (4) kualitas SDM yang rendah sebagai akibat keterbatasan akses pendidikan, kesehatan, dan pelayanan publik, (5) degradasi sumber daya lingkungan, baik di kawasan pesisir, laut, maupun pulau-pulau kecil, dan (6) belum kuatnya kebijakan yang berorientasi pada kemaritiman sebagai pilar utama pembangunan nasional (Kusnadi, 2006).

Sektor perikanan merupakan salah satu sumber PAD yang penting bagi seluruh kabupaten di Kawasan Indonesia Timur (KTI). Di beberapa kabupaten di KTI sektor perikanan menempati urutan pertama sampai kedua dalam Product Domestic Ragional Bruto (PDRB) dan menunjukkan adanya peningkatan kontribusi terhadap PDRB dari tahun ke tahun. Ini terjadi karena potensi sektor perikanan daerah-daerah tersebut sangat besar dan secara geografis memiliki garis pantai yang sangat panjang. Peningkatan PAD dan besarnya kontribusi sektor perikanan terhadap PDRB tersebut masih dapat terus ditingkatkan melalui peningkatan produksi perikanan dengan memotivasi anggota masyarakat untuk memanfaatkan sumber daya perikanan yang ada di daerah yang bersangkutan secara optimal, disertai dengan peningkatan kualitas sarana dan prasarana produksi perikanan yang ada (Syamsuddin, 2010).

Wilayah Kabupaten Takalar memiliki potensi kelautan dan perikanan yang cukup besar. Kabupaten Takalar memiliki banyak daerah pantai yang berpotensi terhadap subsektor perikanan, khususnya penangkapan ikan laut. Dilihat dari produksi perikanan tangkap di Kabupaten Takalar setiap tahun mengalami peningkatan yang berarti tingkat pendapatan nelayan tentu lebih baik yang tercermin dari kehidupan nelayan itu sendiri, karena produksi berhubungan dengan pendapatan, apabila produksi meningkat tentunya pendapatan juga akan meningkat, namun pada kenyataan yang dilihat dari struktur sosial 
Wardihan Sabar, Nur Indasari, Determinan Tingkat Pendapatan Nelayan Perahu Motor Tempel

kehidupan nelayan di Kabupaten Takalar khususnya di Kecamatan Galesong Utara belum mencerminkan tingkat pendapatan yang lebih baik.

Rendahnya pendapatan nelayan merupakan salah satu faktor akibat rendahnya produktifitas nelayan yang ada di Desa Tamasaju Kecamatan Galesong Utara Kabupaten Takalar. Jika tidak bekerja, nelayan tidak akan mendapatkan penghasilan untuk membiayai kebutuhan sehari-hari dan akan mengakibatkan tingkat kesejahteraan masyarakat nelayan semakin menurun.Modal kerja merupakan hal yang mempengaruhi pendapatan nelayan. Dengan tersedianya modal yang memadai maka nelayan dapat meningkatkan produksi karena nelayan dapat membeli perahu, alat tangkap, bahan bakar minyak, dan peralatan lainnya,serta biaya operasional nelayan dalam melaut.

Dari sisi modal kerja, sebagai input produksi nelayan, nelayan tersebut membutuhkan faktor-faktor utama yang memberikan keberhasilan kinerjanya, salah satunya adalah Bahan Bakar Minyak (BBM). BBM merupakan komoditas yang memegang peranan sangat vital dalam semua aktifitas ekonomi.Dalam perekonomian global saat ini, harga minyak dunia terus meningkat seiring dengan menurunnya kapasitas cadangan. Hal tersebut yang kemudian di Indonesia juga mengalami peningkatan harga minyak mentah yang ada seiring dengan perkembangan harga minyak mentah utama di pasar internasional.

Kenaikan harga BBM jelas akan berdampak ke masyarakat luas hingga masyarakat kecil. Sebagai contoh, dengan naiknya harga premium atau solar sebagai bahan bakar transportasi nelayan akan menyebabkan naiknya ongkos produksi. Dengan kenaikan ongkos produksi tersebut akan mendorong kenaikan harga jual hasil tangkapan nelayan (output). Lamanya melaut dalam sekali melaut turut serta dalam penelitian ini. Waktu yang paling efektif dalam sekali melaut adalah malam hingga pagi hari dengan jarak tempuh sekitar tiga hingga empat mill berkisar tujuh sampai delapan jam perhari. Dengan menggunakan Perahu Motor Tempel dan alat tangkap yang sederhana maka kurun waktu ini dianggap waktu yang efektif untuk melaut diluar jam kegiatan lainnya.

Umur dapat berpengaruh bagi nelayan dalam mengambil keputusan. Umur muda memungkinkan nelayan lebih dinamis dan lebih dapat menerima inovasi baru. Dengan kondisi tersebut nelayan mampu mengelola usahanya seoptimal mungkin dengan curahan tenaga fisik yang tersedia.

Pengalaman kerja atau lamanya menjadi seorang nelayan adalah faktor yang juga dianggap penting dalam penelitian ini. Dikarenakan semakin lama seorang nelayan mencari mata pencahariannya dilaut maka tingkat pengalamannya juga akan semakin besar. Dengan hal ini, kecenderungan pendapatan nelayan juga dianggap meningkat.Berbagai jenis mesin penggerak perahu yang digunakan oleh nelayan dalam melaksanakan usahanya, mulai dari 
merk mesin hingga variasi daya yang dihasilkan oleh mesin itu sendiri dengan berdasarkan lama waktu penangkapan dan ukuran perahunya. Salah satunya yaitu perahu motor tempal yang digunakan sebagian besar nelayan yang ada di Kecamatana Galesong UtaraKabupaten Takalar.

Perahu motor tempel memiliki kegunaan untuk menggerakkan perahu bila angin mati, untuk mengefisienkan arah perahu karena dapat memotong alun, untuk mempercepat jalur pelayaran, untuk menempuh jarak yang lebih jauh sehingga dapat memperoleh ikan tangkap yang lebih bermutu. Kapal atau perahu motor tempel disebut juga kapal perikanan bermotor luar (out board). Kapal jenis ini dioperasikan dengan menggunakan mesin penggerak diluar kasko dan merupakan usaha penangkapan berskala kecil atau tradisional. Nelayan perahu motor tempel terdiri dari dua atau tiga orang, terdiri dari juru mudi dan ABK. Juru mudi bertugas menentukan daerahpenangkapan ikan sekaligus mengemudikan perahu, ABK bertugas mengoperasikan alat tangkap dan di bantu juga oleh nahkoda (Rahmi, dkk, 2013).

\section{TINJAUAN TEORITIK / LITERATURE REVIEW}

Produksi dapat didefinisikan sebagai hasil dari suatu proses atau aktivitas ekonomi dengan memanfaatkan beberapa masukan input. Dengan demikian, kegiatan produksi tersebut adalah mengombinasikan berbagai input untuk menghasilkan output (Agung, dkk, 2013). Produksi mempunyai ragam batasan dari ahli. Produksi dapat diartikan yaitu menghasilkan sejumlah output produksi adalah hasil yang diperoleh sebagai akibat dari bekerjanya faktor-faktor produksi. Yang termasuk dalam produksi ini adalah tanah, modal, dan tenaga kerja. Produksi merupakan hasil akhir dari proses atau aktivitas ekonomi dengan memanfaatkan beberapa masukan atau input. Produksi atau memproduksi menambah kegunaan suatu barang. Kegunaan suatu barang akan bertambah bila memberikan manfaat baru atau lebih dari bentuk semula.

Produksi merupakan suatu gambaran yang menunjukkan adanya hubungan antara tingkat produksi suatu barang dan jasa dengan jumlah faktor-faktor produksiyang digunakan untuk menghasilkan barang tersebut. Lebih lanjut dijelaskan bahwa fungsi produksi adalah hubungan fisik antara masukan dengan keluaran produksi.Dalam teori ekonomi, setiap proses produksi mempunyai landasan teknis yang disebut fungsi produksi. Fungsi produksi 
Wardihan Sabar, Nur Indasari, Determinan Tingkat Pendapatan Nelayan Perahu Motor Tempel

adalah fungsi atau persamaan yang menunjukkan hubungan fisik atau teknis antara jumlah faktor produksi yang dipergunakan dengan jumlah produk yang dihasilkan per satuan waktu tanpa memerhatikan harga, baik harga faktor produksi maupun harga produk.

Fungsi Produksi:

$Q=f(K, L)$

Dimana $\mathrm{Q}$ fungsi dari $\mathrm{K}$ dan $\mathrm{L}$, dalam hal ini $\mathrm{Q}$ di pandang sebagai variabel tak bebas (dependent variabel) dan input $K$ dan $L$ sebagai variabel bebas (independent variabel).

Secara matematis, fungsi produksi dapat dinyatakan:

$Y=f(X 1, X 2, X 3, \ldots \ldots, X n)$.

Dimana:

$\mathrm{Y}=$ Tingkat produksi (output) yang dihasilan.

$\mathrm{X} 1, \mathrm{X} 2, \mathrm{X} 3$ = Berbagai faktor produksi (input) yang digunakan.

Fungsi ini masih bersifat umum, hanya menjelaskan bahwa produk yang dihasilkan bergantung pada faktor-faktor produksi yang dipergunakan, tetapi belum bisa memberikan penjelasan kuantitatif mengenai hubugan antara produk dan faktor-faktor produksi. Untuk memberikan penjelasan kuantitatif, fungsi produksi harus dinyatakan dalam bentuk yang spesifik, misalnya:

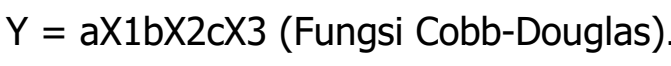

Fungsi produksi Cobb-Douglas adalah suatu fungsi atau persamaan yang melibatkan dua atau lebih variabel, dimana varibel yang satu disebut dengan devenden, yang dijelaskan $(Y)$ dan yang lainnya disebut variabel independen yang menjelaskan (X). penyelesaian hubungan antara $\mathrm{Y}$ dan $\mathrm{X}$ biasanya dengan cara regresi, yaitu variasi dari $\mathrm{Y}$ akan dipengaruhi oleh dari $\mathrm{X}$.

Fungsi produksi Cobb-Douglas sering disebut fungsi produksi eksponensial. Kelebihan Cobb-Douglas ini adalah pangkat menunjukkan tingkat elastisitas produksi. Sedangkan kelemahannya adalah dalam interpretasi perlu dilinierkan dengan proses logaritma atau sering disebut dengan double $\log ; \log Y=\log a+\log b X$ (Masyhuri, 2007).

Perpaduan terhadap persamaan 1, maka persamaan tersebut diubah menjadi bentuk linear berganda dengan cara melogaritmakan persamaan tersebut. Untuk memudahkanpenjelasan maka persamaan 1 dituliskan kembali, yaitu:

$Y=f(X 1, X 2, \ldots X n)$

Logaritma dari persamaan diatas adalah:

$\log Y=\log a+b 1 \log X 1+b 2 \log X 2+b n \log X n+e$.

Dimana :

$\mathrm{Y}=$ Produksi 
$\mathrm{Xi} \quad=$ Faktor Produksi $(\mathrm{X} 1, \mathrm{X} 2, \mathrm{X} 3, \ldots \mathrm{Xn})$

Persamaan ini dapat dengan mudah diselesaikan dengan cara regresi berganda. Pada persamaan tersebut terlihat bahwa nilai b1 dan b2 tetap walaupun variabel terlibat telah dilogaritmakan. Hal ini dapat dimengerti karena b1 dan b2 pada fungsi Cobb-Douglas sekaligus menunjukkan elastisitas $\mathrm{X}$ terhadap $\mathrm{Y}$.

Faktor-faktor produksi dibedakan menjadi 4 golongan: tanah, tenaga kerja, modal, dan keahlian keusahawanan. Apabila faktor-faktor produksi itu digunakan untuk mewujudkan barang dan jasa akan diperoleh berbagai jenis pendapatan, (Sukirno, 2012).

Pendapatan akan mempengaruhi banyaknya barang yang dikonsumsikan, bahwa seringkali dijumpai dengan bertambahnya pendapatan, maka barang yang dikonsumsi bukan saja bertambah, tapi juga kualitas barang tersebut ikut menjadi perhatian. Misalnya sebelum adanya penambahan pendapatan beras yang dikonsumsikan adalah kualitas yang kurang baik, akan tetapi setelah adanya penambahan pendapatan maka konsumsi beras menjadi kualitas yang lebih baik, (Soekartawi, 2012).

Pendapatan merupakan hasil pengurangan dari total revenue (TR) dengan total cost (TC), dapat di tuliskan sebagai berikut:

$$
\text { Л= TR }-\mathrm{TC}
$$

Yang dimana penerimana total (TR) yaitu total penerimaan produsen dari hasil penjualan produksinya. Sehingga penerimaan total adalah jumlah produksi yang terjual dikalikan dengan harga jual produk.

Penerimaan revenue dapat dituliskan dengan:

$\mathrm{TR}=\mathrm{Pq} \times \mathrm{Q}$

Biaya total (TC) adalah keseluruhan jumlah biaya produksi yang dikeluarkan, dimana terdiri dari penjumlahan antara biaya tetap total [TFC ( total fixed cost)] dan biaya berubah total [TVC (total variabel cost).

Biaya dapat dituliskan dengan:

$\mathrm{TC}=\mathrm{TFC}+\mathrm{TVC}$

Yang dimana biaya tetap total (TFC) adalah keseluruhan biaya yang dikeluarkan untuk memperoleh faktor produksi (input) yang tidak dapat diubah jumlahnya, jadi berapapun tingkat produksi yang dihasilkan produsen, maka ia harus menanggung biaya yang sama besarnya, misalnya mesin. Sedangkan biaya berubah total (TVC) adalah 
Wardihan Sabar, Nur Indasari, Determinan Tingkat Pendapatan Nelayan Perahu Motor Tempel

keseluruhan biaya yang dikeluarkan untuk memperoleh faktor produksi yang dapat diubah jumlahnya sesuai dengan jumlah produksi yang dihasilkan. Dimisalkan faktor produksi yang dapat berubah jumlahnya adalah tenaga kerja, ((Arif, 2010).

Pendapatan usaha nelayan adalah selisih antara penerimaan (TR) dan semua biaya (TC). Jadi Pd = TR-TC. Penerimaan usaha nelayan (TR) adalah perkalian antara produksi yang diperoleh dengan harga jual. Biaya usaha nelayan biasanya diklasifikasikan menjadi dua yaitu biaya tetap (fixed cost)dan biaya tidak tetap (variabel cost). Biaya tetap (FC) adalah biaya yang relatif tetap jumlahnya dan terus dikeluarkan walaupun produksi yang diperoleh banyak atau sedikit. Biaya variabel (VC) adalah biaya yang besar kecilnya dipengaruhi oleh produksi yang diperoleh, contoh biaya untuk tenaga kerja. Total biaya (TC) adalah jumlah dari biaya tetap (FC) dan biaya variabel (VC), maka TC = FC+VC.

Setiap nelayan menginginkan perolehan pendapatan yang memadai dari jenis usahanya. Hasil nyata yang telah dirasakan manfaat dari kegiatannya yaitu meningkatkan produksi dan produktifitas tangkapannya. Tingginya capaian tersebut secara langsung dapat meningkatkan pendapatan nelayan, dari pendapatan tersebut mereka mampu membiayai berbagai kebutuhan hidupnya, seperti sandang, pangan, papan, perumahan, dan bahkan dapat membiayai kebutuhan anak-anaknya. Meningkatnya berbagai kebutuhan tersebut mendorong para nelayan untuk berusaha meningkatkan jumlah pendapatannya.

\section{METODE PENELITIAN / METHODS}

Metode penelitian yang digunakan dalam penelitian ini yaitu metode penelitian kuantitatif, dengan pendekatan eksplanatori. Alasan utama pemilihan jenis penelitian eksplanatori ini untuk menguji hipotesis yang diajukan agar dapat menjelaskan pengaruh variabel bebas (biaya bahan bakar minyak, lama melaut, umur nelayan, dan pengalaan nelayan) terhadap variabel terikat (pendapatan nelayan perahu motor tempel) baik secara parsial maupun simultan yang ada dalam hipotesis tersebut.

Data yang digunakan yaitu data yang bersumber dari wawancara langsung kepada nelayan dengan menggunakan daftar pertanyaan (kuisioner) untuk mengetahui tingkat pendapatan nelayan perahu motor tempel. Data primer yang dikumpul meliputi: pendapatan nelayan perbulan, biaya bahan bakar minyak, lama melaut, umur nelayan, pengalaman melaut serta data lain yang berkaitan dengan penelitian ini.

Dalam penelitian ini menggunakan model Analisis Regresi Linear Berganda dengan model kuadran terkecil (Ordinary Least Square/ OLS). Analisis ini digunakan untuk mengetahui faktor-faktor yang mempengaruhi pendapatan nelayan perahu motor tempel adalah analisis regresi berganda yang dinyatakan dalam bentuk fungsi sebagai berikut: 
$\pi N T=\beta 0$ Bbbm $\beta 1$ Lm $\beta 2$ Umrß3 Pnglm $\beta 4 \mu i$

Karena satuan setiap variable majemuk maka harus dilogaritma naturalkan sehingga linear maka membentuk persamaan sebagai berikut :

$\operatorname{Ln} n N T=\beta 0+\beta 1 \operatorname{LnBbbm}+\beta 2 \operatorname{LnLm}+\beta 3 \mathrm{LnUmr}+\beta 4 \operatorname{LnPnglm}+\mu \mathrm{i}$

Dimana :

пNT : Pendapatan Nelayan Tangkap (Rp/trip)

Bbbm = Biaya bahan bakar minyak (RP/bulan )

Lm = Lama melaut (jam/bulan)

Umr = Umur Nelayan (Tahun)

Pnglm = Pengalaman Melaut (Tahun)

$\beta 0=$ Konstanta

$\beta 1-\beta 4=$ Parameter

Ln $\quad=$ Logaritma Natural

$\mu \quad=$ Error Term

Pengukuran goodness of fit dihitung dengan adjusted R2. Menurut Gujarati and Porter (2009) dirumuskan sebagai berikut :

Adjusted $R^{\wedge} 2=1-\left(1-R^{\wedge} 2\right)((n-1)) /((k-1)$

Dimana :

Adjusted R2 : koefisien determinasi yang disesuakan

k : jumlah variabel yang tidak termasuk intersep

n : jumlah sampel

Pengujian hipotesis terhadap koefisien regresi secara bersama-sama digunakan uji-F dengan tingkat kepercayaan tertentu, yang menurut Greene (1990) serta Gujarati and Porter (2009) dirumuskan sebagai berikut :

F hitung $=(E S S /(k-1)) /(R S S /(n-k))$

Ftabel $[(k-1):(n-k) ; a]$

Dimana :

$\alpha$ : tingkat signifikan

Pengujian terhadap koefisien regresi secara parsial digunakan uji $t$ dengan tingkat kepercayaan tertentu. Menurut Greene (1990) serta Gujarati and Porter (2009) dengan rumus : 
t hitung $=\beta i / S \beta i$.

t tabel $[(n-k) ; a / 2]$

Dimana :

i : koefisien regresi ke-i

S.i : standard error koefisien regresi ke-i

Selanjutnya pengujian multikolinearitas (Farrar and Glauber, 1967)dengan metode VIF (variance inflation factor) yang menurut (Gujarati and Porter, 2009) dirumuskan :

$\mathrm{VIF}=1 /\left(1-R_{-} j^{\wedge} 2\right)$

R2j diperoleh dari regresi auxilary antara variabel independen atau koefisien determinasi antara variabel bebas ke-j dengan variabel bebas lainnya. Jika nilai VIF lebih kecil dari 10 maka tidak terdapat multikolinearitas. Lain halnya pengujian heterokedastisitas dengan park test (Park, 1966) berikut :

$$
\begin{aligned}
\operatorname{Ln} \text { êi2 }=\operatorname{Ln} \sigma 2 & +\beta \operatorname{Ln} X i+v i \ldots \\
= & a+\beta \operatorname{Ln} X i+v i
\end{aligned}
$$

Jika koefisien $(\beta)$ tidak signifikan, maka disimpulkan tidak terdapat heterokedastitas karena varian residualnya tidak tergantung dari variabel independen, sebaliknya jika $\beta$ signifikan maka mengandung unsur heterokedastitas karena besar kecilnya varian residual ditentukan oleh variabel independen (Park, 1966; Gujarati and Porter, 2009).

\section{HASIL DAN PEMBAHASAN / DISCUSSION}

Persamaan regresi dapat dilihat dari tabel hasil uji coefisient berdasarakan output SPSS terhadap keempat variabel independen yaitu biaya bahan bakar minyak, lama melaut, umur nelayan, dan pengalaman melaut terhadap variabel dependen yaitu pendapatan nelayan perahu motor tempel. Berikut adalah tabel ringkasan analisis linear berganda:

\section{Tabel. 1. Tabel 4.14: Hasil Analisis Regresi}

\begin{tabular}{lccr}
\hline Variabel Independen & $\beta$ & t- Hit & Sign \\
\hline Biaya Bahan Bakar Minyak & 1.242 & 5.810 & .000 \\
Lama Melaut & -.599 & -1.311 & .195 \\
Umur Nelayan & -.126 & -.512 & .611 \\
Pengalaman Melaut & 0.49 & .452 & .653 \\
\hline Konstanta & & & 1.802 \\
\hline F Hitung & & & 10.239 \\
\hline Adjusted $\mathrm{R}^{2}$ & & & .385 \\
\hline Sampel $(\mathrm{n})$ & & & 60
\end{tabular}

Sumber: Hasil Olah Data SPSS, Tahun 2017. 
Berdasarkan hasil analisis regresi maka dihasilkan persamaan regresi sebagai berikut:

LnPn $=1.802+1.242$ LnBbbm - 0.599 LnLm -0.126 LnUmr + 0.049 LnPnglm + e

0.307

Dari persamaan diatas, diubah kembali dalam fungsi keuntungan Cobb Douglas dengan menganti Ln sebagai berikut:

LnPn = anti Ln 1.802 Bbbm1.242 Lm-0.599 Umr-0.126 Pnglm0.049e0.307

$=1.802$ Bbbm1.242 Lm-0.599 Umr-0.126 Pnglm0.049e0.307

Nilai koefisien $\beta 0$ sebesar 1.802, angka tersebut menunjukkan bahwa jika biaya bahan bakar minyak (X1), lama melaut (X2), umur nelayan (X3), pengalaman melaut (X4) nilainya 0 atau konstan maka pendapatan nelayan perahu motor tempel sebesar 1.802 Rupiah.

Variabel bebas biaya bahan bakar minyak (X1) mempunyai koefisien regresi $\beta 1$ sebesar 1.242 menunjukkan pengaruh biaya bahan bakar minyak responden yang bernilai positif $(+)$. Artinya apabila bahan bakar minyak responden bertambah 1 persen solar maka akan menyebabkan pertambahan pendapatan sebesar 1.242 Rupiah dengan asumsi lama melaut (X2), umur nelayan (X3) dan pengalaman melaut (X4) dianggap konstan.

Variabel bebas lama melaut (X2) mempunyai koefisien regresi $\beta 2$ sebesar -0.599 menunjukkan pengaruh lama melaut responden yang bernilai positif (-). Artinya apabila lama melaut responden bertambah 1 jam maka akan menyebabkan penurunan pendapatan sebesar 0.599dengan asumsi biaya bahan bakar minyak (X1), umur nelayan (X3) dan pengalaman melaut (X4) dianggap konstan.

Variabel bebas umur nelayan (X3) mempunyai koefisien regresi $\beta 3$ sebesar -0.126 menunjukkan pengaruh umur nelayan responden yang bernilai negatif (-). Artinya apabila umur nelayan responden bertambah 1 tahun maka akan menyebabkan penurunan pendapatan sebesar 0.126dengan asumsi biaya bahan bakar minyak (X1), lama melaut (X2) dan pengalaman melaut (X4) dianggap konstan.

Variabel pengalaman melaut (X4) mempunyai koefisien regresi $\beta 4$ sebesar 0.049 menunjukkan pengaruh pengalaman melaut responden yang bernilai positif $(+)$. Artinya apabila pengalaman melaut responden bertambah 1 tahun maka akan menyebabkan pertambahan pendapatan sebesar 0.049dengan asumsi bahan bakar minyak (X1), lama melaut (X2), umur nelayan (X3) dan dianggap konstan. 
Wardihan Sabar, Nur Indasari, Determinan Tingkat Pendapatan Nelayan Perahu Motor Tempel

Tabel 4.13 menunjukkan bahwa hasil dari perhitungan diperoleh nilai koefisien determinasi Adjusted R Square sebesar 0.385, yang artinya bahwa 38,5\% variasi perubahan pendapatan nelayan perahu motor tempel di Desa Tamasaju dapat dijelaskan oleh variabel bebas yaitu biaya bahan bakar minyak, lama melaut, umur nelayan, dan pengalaman melaut sedangkan sisanya sebesar $61.5 \%$ dipengaruhi oleh variabel-variabel lain yang tidak termasuk dalam penelitian.

Perhitungan uji $\mathrm{F}$ dapat dilihat pada tabel 4.13. Dari hasil regresi pengaruh variabel biaya bahan bakar minyak (X1), lama melaut (X2), umur nelayan (X3), dan pengalaman melaut (X4) terhadap pendapatan nelayan perahu motor tempel $(Y)$, maka diperoleh nilai Fhitung sebesar 10.239 dengan signifikansi sebesar 0.000 lebih kecil dari taraf signifikansi yang digunakan dalam penelitian ini yaitu $0.05(0.000<0.05)$. Hal ini menunjukkan bahwa keempat variabel independen secara simultan atau bersama-sama berpengaruh signifikan terhadap variabel dependen.

Uji t dilakukan untuk mengetahui pengaruh variabel independen(biaya bahan bakar minyak, lama melaut, umur nelayan, dan pengalama melaut) secara parsial terhadap variabel dependen (pendapatan nelayan perahu motor tempel di Desa Tamasaju Kecamatan Galesong Utara Kabupaten Takalar) dan menganggap variabel lain konstan. Signifikansi tersebut dapat diestimasi dengan membandingkan antara nilai ttabel dengan thitung.

Berdasarkan tabel 4.13 perhitungan uji $\mathrm{t}$ dapat dilihat hasil pengujian parsial terhadap masing-masing variabel independen (biaya bahan bakar minyak, lama melaut, umur nelayan dan pengalaman nelayan) secara parsial terhadap variabel dependennya (Pendapatan nelayan perahu motor tempel di Desa Tamasaju Kecamtan Galesong Utara Kabupaten Takalar dapat dianalisa sebagai berikut.

Pengaruh Biaya bahan bakar minyak terhadap pendapatan nelayan perahu motor temple:

Berdasarkan tabel 4.13di dapatkan nilai koefisien biaya bahan bakar minyak sebesar 1.242 dan nilai signifikansi untuk variabel biaya bahan bakar minyak adalah 0.000 dinyatakan lebih kecil dari taraf $a=0.05(0.000<0.05)$. Hal ini menunjukkan juga dengan nilai thitung $=5.810$ dan nilai ttabel dengan tingkat signifikan $5 \%(0.05)$ pada derajat kebebasan $60-5=55$ adalah1.673, sehingga thitung> ttabel $(5.810>1.673)$. Dari hasil tersebut sehingga dapat disimpulkan bahwa variabel biaya bahan bakar minyak mempunyai pengaruh positif dan signifikan terhadap pendapatan nelayan perahu motor tempel di Desa Tamasaju Kecamatan Galesong Utara, Kabupaten Takalar. Hal ini sesuai dengan hipotesis sebelumnya bahwa biaya bahan bakar minyak berpengaruh positif terhadap pendapatan nelayan. 
Hasil penelitian ini menunjukkan bahwa biaya bahan bakar minyak berpengaruh signifikan terhadap pendapatan nelayan di Desa Tamasaju. Sehingga untuk mendapatkan penambahan pendapatan yang lebih besar harus diikuti dengan penambahan biaya bahan bakar minyak yang lebih besar lagi.Bahan bakar minyak merupakan salah satu komponen penting dalam suatu operasi penangkapan ikan. Komponen ini menyumbang $50-70 \%$ dari total biaya operasi (Muchlisin, 2012).Komponen bahan bakar minyak (BBM) khususnya solar merupakan komponen biaya terbesaryang dikeluarkan oleh nelayan dalam melaut dan biaya konsumsi menempati urutan kedua.

Pendapatan usaha penangkapan ikan nelayan diperoleh dari penerimaan dikurangi dengan biaya biaya. Dalam penelitian ini termasuk komponen biaya adalah bahan bakar minyak yang dapat diartikan bahwa untuk setiap penambahan biaya bahan bakar minyak nelayan perahu motor tempel maka akan dapat meningkatkan pendapatan nelayan. Hal tersebut sangat sesuai dengan apa yang terjadi pada nelayan di Desa Tamasaju, karena dengan adanya penambahan modal maka biaya operasional (bahan bakar minyak) dapat ditingkatkan sehingga jarak menangkap ikan akan semakin luas dan kemungkinan untuk mendapatkan ikan akan semakin besar sehingga pendapatan juga akan ikut meningkat. Penelitian ini sejalan dengan penelitian yang dilakukan oleh Adhar (2012), yang menyatakan bahwa modal kerja berpengaruh signifikan terhadap pendapatan usaha nelayan, karena dalam peningkatan modal kerja akan mempengaruhi peningkatan jumlah tangkapan ikan/ produksi sehingga akan meningkatkan pendapatan.

Pengaruh lama melaut dengan pendapatan nelayan perahu motor tempel Berdasarkan tabel 4.13di dapatkan nilai koefisien lama melaut sebesar -0.599 dan nilai signifikansi untuk variabel biaya bahan bakar minyak adalah 0.195 dinyatakan lebih kecil dari taraf $a=0.05(0.195>0.05)$. Hal ini menunjukkan juga dengan nilai thitung $=-1.311$ dan nilai ttabel dengan tingkat signifikan 5\% (0.05) pada derajat kebebasan $60-5=55$ adalah 1.673 , sehingga thitung $<$ ttabel $(-1.311<1.673)$. Dari hasil tersebut sehingga dapat disimpulkan bahwa variabel lama melautberpengaruh negatifdan tidak signifikan terhadap pendapatan nelayan perahu motor tempel di Desa Tamasaju Kecamatan Galesong Utara Kabupaten Takalar. Hal ini tidak sesuai dengan hipotesis sebelumnya yang menyatakan bahwa lama melaut berpengaruh positif terhadap pendapatan nelayan. 
Wardihan Sabar, Nur Indasari, Determinan Tingkat Pendapatan Nelayan Perahu Motor Tempel

Hasil penelitian ini menunjukkan lama melaut berpengaruh negatif terhadap pendapatan nelayan perahu motor tempel di Desa Tamasaju. Lamanya melaut nelayan secara teori berpengaruh terhadap pendapatan nelayan, hal ini tidak sejalan dengan nelayan perahu motor tempel di Desa Tamasaju karenaapabila nelayan perahu motor tempel di Desa Tamasaju melaut dalam waktu yang sangat lama dalam menangkap ikan, maka pendapatan usaha tangkapnya menurun.Penelitian ini tidak sejalan dengan penelitian yang dilakukan oleh Jamal (2014), yang menyatakan bahwa variabel curahan jam kerja secara parsial berpengaruh signifikan terhadap pendapatan nelayan di Desa Klampis. Semakin lama waktu yang curahkan nelayan untuk melaut mengartikan bahwa semakin banyak waktu yang digunakan untuk berproduksi (mencari ikan). Hal tersebut tentu akan berdampak positif terhadap pendapatan nelayan yang bersangkutan. Semakin panjang waktu melaut maka semakin besar pula potensi ikan yang ditangkap, dengan demikian semakin besar juga potensi pendapatan yang diperoleh.

Lamanya perjalanan merupakan waktu yang diperlukan nelayan untuk sampai ditempat sasaran penangkapan ikan, hal ini sangat dipegaruhi oleh berapa lama nanti nelayan berada di lautan untuk dapat mencari tepat yang ideal. Semakin lama nelayan di laut, maka ikan yang dihasilkan juga semakin banyak dan dapat diasumsikan semakin banyak waktu di laut, maka ikan yang dihasilkan juga semakin banyak tergantung dari ikan yang didapatkan.Lama melaut nelayan kecil atau yang biasa disebut dengan perahu motor tempel yang berada di Desa Tamasaju menggunaan waktunya untuk mencari ikan di laut hanya berkisar antara satu sampai dua hari karena muatan dan kapalyang digunakan nelayan di Desa Tamasaju tersebut tidak mampu untuk melaut terlalu jauh dengan menggunakan waktu yang sangat lama dan juga alat yang digunaka nelayan perahu motor tempel di Desa Tamasaju masih standar.

Pengaruh umur nelayan terhadap pendapatan nelayan perahu motor temple:

Berdasarkan tabel 4.13di dapatkan nilai koefisien umur nelayan sebesar -0.126 dan nilai signifikansi untuk variabel umur nelayan adalah 0.611 dinyatakan lebih besar dari taraf $a=$ $0.05(0.611>0.05)$. Hal ini menunjukkan juga dengan nilai thitung $=-0.512$ dan nilai ttabel dengan tingkat signifikan 5\% (0.05) pada derajat kebebasan $60-5=55$ adalah 1.673, sehingga thitung < ttabel $(-0.512<1.673)$. Dari hasil tersebut sehingga dapat disimpulkan bahwa variabel umur nelayanberpengaruh negatif dan tidaksignifikan terhadap pendapatan nelayan perahu motor tempel di Desa Tamasaju Kecamatan Galesong Utara, Kabupaten Takalar. Hal ini sesuai dengan hipotesis awal yang menyatakan bahwa umur nelayan berpengaruh negatif terhadap pendapatan nelayan. 
Hasil penelitian ini menunjukkan bahwa umur nelayan tidak berpengaruh terhadap pendapatan nelayan perahu motor tempel di Desa Tamasaju. Hal tersebut sesuai dengan hipotesis sebelumnya yang dimana umur tidak mempengaruhi pendapatan karena pada setiap bidang pekerjaan yang dilakukan, bekerja di umur yang muda tingkat pengalaman kerja masih rendahdan akan mempengaruhi pedapatan dan umur yang tua akan mengurangi produktifitas sehingga umur nelayan di Desa Tamasaju tidak mempengaruhi pendapatannya. Penelitian ini sejalan dengan penelitian yang dilakukan oleh Jume'edi (2005), yang menyatakan bahwa umur cenderung mempengaruhi curahan jam kerja karena pada umumnya semakin bertambah usia seseorang akan semakin tinggi jam waktu kerjanya, namun pada usia tertentu akan menurun sejalan dengan kualitas fisik yang menurun pula.

Begitu pula dengan pendapat Roger dan Meiners yang menyatakan profil usia dan pendapatan sampai batas tertentu, pendapatan meningkat seiring dengan bertambahnya usia masa kerjaseseorang. Lewat dari batas itu, pertambahan usia diiringi dengan penurunan pendapatan. Batas atas titik puncak diperkirakan ada pada usia 45 hingga 55 tahun.

Bertambahnya umur nelayan di Desa Tamasaju tidak mempengaruhi pendapatan nelayan karena dengan bertambahnya umur seorang nelayan maka pengalamannya dalam melaut juga meningkat, akan tetapi pada sampai batas tertentu atau pada batas umur tertentu pendapatan akan menurun seiring berjalannya waktu karena pada usia tua produktifitas seseorang akan menurut begitu pula dengan nelayan sehingga pendapatan nelayan perahu motor tempel di Desa Tamasaju dapat menurun. Penelitian ini juga sejalan dengan penelitian yang dilakukan oleh Abd. Rahim dan Sri Kartini Syam yang menyatakan bahwa umur tidak berpengaruh terhadap pendapatan usaha tangkap nelayan.

Pengaruh pengalaman melaut dengan pendapatan nelayan perahu motor temple: Berdasarkan tabel 4.15 di dapatkan nilai koefisien pengalaman melaut sebesar 0.049 dan nilai signifikansi untuk variabel pengalaman melaut adalah 0.653 dinyatakan lebih besar dari taraf $a=0.05(0.653>0.05)$. Hal ini menunjukkan juga dengan nilai thitung $=0.452$ dan nilai ttabel dengan tingkat signifikan 5\% (0.05) pada derajat kebebasan $60-5=55$ adalah 1.673, sehingga thitung $<$ ttabel $(0.452<1.673)$. Dari hasil tersebut sehingga dapat disimpulkan bahwa variabel pengalaman melautberpengaruh positif namun tidak signifikan 
Wardihan Sabar, Nur Indasari, Determinan Tingkat Pendapatan Nelayan Perahu Motor Tempel

terhadap pendapatan nelayan perahu motor tempel di Desa Tamasaju Kecamatan Galesong Utara, Kabupaten Takalar. Hal ini sesuai dengan hipotesis sebelumnya yang menyatakan bahwa pengalaman melaut berhubungan positif terhadap pendapatan nelayan.

Uji F dilakukan untuk mengetahui pengaruh semua variabel independen yang dimasukkan dalam model mempunyai pengaruh secara bersama-samaterhadap variabel dependennya.Uji F dilakukan dengan membandingkan Fhitung dan Ftabel. Jika nilai taraf signifikasi Fhitung $<a=0.05$ juga dibuktikan dengan jika nilai Fhitung $>$ Ftabel. Jika nilai signifikansi Fhitungdibawah $a=0.05$ dan jika Fhitung> Ftabel maka variabel independen dalam penelitian ini secara bersama-sama berpengaruh terhadap variabel dependen.

Hasil penelitian ini menunjukkan bahwa pengalaman melaut berpengaruh positif, namun tidak signifikan terhadap pendapatan nelayan di Desa Tamasaju. Pengalaman kerja merupakan pengetahuan atau keterampilan yang telah diketahui dan dikuasai seseorang yang akibat dari perbuatan atau pekerjaan yang telah dilakukan selama beberapa waktu tertentu.

Menurut Winardi (1988),faktor pengalaman kerja nelayan yang semakin berpengalaman dalam melaut bisa meningkatkan pendapatannya, dikarenakan orang yang berpengalaman dapat mengetahui lokasi dimana saja ikan-ikan bergerombolan disaat tertentu. Semakin lama pengalaman usaha nelayan semakin besar peluang mendapatkan hasil tangkapan yang lebih banyak, disebabkan karena usaha nelayan tidak menggunakan pedoman atau tekhnologi untuk mengetahui lokasi-lokasi penangkapan ikan, tetapi hanya mengandalkan pengalaman kerja dilaut.Dengan pengalaman yang memadai seorang nelayan akan dengan mudah mendapatkatkan hasil tangkapannya karena seorang nelayan yang berpengalaman dapat mengetahui dimana tempat ikan berkumpul dan menangkapnya dengan kemampuannya.

Berdasarkan hasil regresi variabel pengalaman melaut berpengaruh positif namun tidak signifikan terhadap pendapatan nelayan perahu motor tempel. Semakin lama nelayan melaut menjadikan mereka semakin banyak mendapatkan pengalaman tentang cara melaut sehingga mereka jadi semakin tahu bagaimana cara mendapatkan ikan yang lebih baik.

Hasil penelitian ini tidak sejalan dengan penelitian yang dilakukan oleh Karof Alfentino Lamia (2013), yang menemukan bahwa pengalaman mempunyai pengaruh signifikan terhadapa pendapatan. Sementara itu, tidak signifikannya pengalaman melaut terhadap pendapatan nelayan perahu motor tempel disebabkan karena karakteristik nelayan yang cenderung monoton dari tahun ke tahun. Tidak ada inovasi baru yang muncul tentang tata cara melaut, mereka cenderung mengikuti cara yang bersifat trandisional sehingga produksi ikan yang dihasilkan tidak mengalami peningkatan, para nelayan juga sulit untuk 
diajak berkumpul untuk membahas tentang tata cara melaut dengan baik, yang ada di pikiran mereka hanya melaut dan mendapatkan uang tanpa memikirkan bagaimana agar dapat mengalami perkembangan.

\section{KESIMPULAN / CONCLUSION}

Faktor yang mempengaruhi pendapatan nelayan perahu motor tempel di Desa Tamasaju Kecamatan Galesong Utara Kabupaten Takalar secara simultan dipengaruhi oleh biaya bahan bakar minyak (X1), lama melaut (X2), umur nelayan (X3), dan pengalaman melaut (X4). Faktor yang mempengaruhi pendapatan nelayan perahu motor tempel di Desa Tamasaju Kecamatan Galesong Utara Kabupaten Takalar secara parsial dipengaruhi oleh variabel biaya bahan bakar minyak dan pengalaman melaut (X4). Variable lama melaut (X2) dan umur nelayan (X3) tidak berpengaruh terhadap pendapatan nelayan perahu motor temple. Untuk meningkatkan pendapatan nelayan, pihak pemerintah harus membantu nelayan dalam hal pemasaran hasil tangkapan dan penggunaan teknologi dibidang penangkapan ikan, serta untuk mendorong kemampuan dari nelayan, maka pemerintah setempat dapat memberikan pembinaan dan pengembangan kemampuan nelayan dalam menangkap ikan.

\section{DAFTAR PUSTAKA / REFERENCES}

Addini, Ikhtaroma, 2016. Praktek Sosial Nelayan Sebelum Melaut di Kelurahan Blimbing Kecamatan Paciran Kabupaten Lamongan. Jurnal. Fakultas Ilmu Sosial dan Hukum, Volume 04 Nomor 03.

Al Arif, M. Nur Rianto, Euis Amalia, 2010. Teori Mikroekonomi Suatu Perbandingan Ekonomi Islam dan Ekonomi Konvensional. Jakarta: Kencana.

Anggia Rahmi Tiara, dkk , 2013. Usaha Perikanan Tangkap Skala Kecil di Sedang, Provinsi Istimewa Yogyakarta, Jurnal "Amanisal" PSP FPIK Unpatti- Ambon.

Badan Pusat Statistik Sulawesi Selatan, 2016. Kabupaten Takalar Dalam Angka.

Badan Pusat Statistik Sulawesi Selatan, 2016. Kecamatan Galesong Utara Dalam Angka

Imron, Masyuri. Kemiskinan Dalam Masyarakat Nelayan. Jurnal. Jakarta: PMB-UPI, 2003.

Jamal, Bahrul. Analisis Faktor-faktor Yang Mempengaruhi Pendapatan Nelayan (Study Nelayan Desa Klampis Kebupaten Bangkalan). Jurnal Universitas Brawijaya Malang. 
Wardihan Sabar, Nur Indasari, Determinan Tingkat Pendapatan Nelayan Perahu Motor Tempel

Kusnadi, 2006. Filosofi Pemberdayaan Masyarakat Pesisir. Bandung: Humaniora.

Kusnadi, 2009. Keberdayaan Nelayan dan Dinamika Ekonomi Pesisir. Yogyakarta.

Masyhuri, 2007. Ekonomi Mikro. UIN Malang Press.

Mulyadi, 2007. Ekonomi Kelautan. Jakarta: PT. Raja Grafindo Persada.

Ngurah Agung, I Gusti, 2004. Statistika Penerapan Metode Analisis untuk Tabulasi Sempurna dan Tak Sempurna dengan SPSS. Jakarta: PT. Raja Grafindo Persada.

Perdana Gumilang, Andi, 2010. Tingkat Pendapatan Usaha Penangkapan Ikan Akibat Kenaikan Harga BBM Pada Nelayan Payang Di Ppi Bandengan Kecamatan Mundu Kabupaten Cirebon. Skripsi: Institut Pertanian Bogor.

Prakoso, Jati, 2013. Peranan Tenaga Kerja, Modal, dan Tekhnologi Terhadap Pendapatan Masyarakat Nelayan Di Desa Asemdayong Kecamatan Taman Kabupaten Pamalang. Skripsi Universitas Negeri Malang.

Rahim, Abd, and Diah Retno Dwi Hastuti. "Determinan Pendapatan Nelayan Tangkap Tradisional Wilayah Pesisir Barat Kabupaten Barru." Jurnal Sosial Ekonomi Kelautan dan Perikanan 11.1 (2016): 75-88.

Rahim, A., \& Hastuti, D. R. D. (2016). Determinan Pendapatan Nelayan Tangkap Tradisional Wilayah Pesisir Barat Kabupaten Barru. Jurnal Sosial Ekonomi Kelautan dan Perikanan, 11(1), 75-88.

Rahim, Abd; Hastuti, Diah Retno Dwi. Determinan Pendapatan Nelayan Tangkap Tradisional Wilayah Pesisir Barat Kabupaten Barru. Jurnal Sosial Ekonomi Kelautan dan Perikanan, 2016, 11.1: 75-88.

Sri Eko Wiyono, Pengaruh Lama Melaut dan Jumlah Hauling terhadap Hasil Tangkapan Ikan pada Perikanan Gillnet Skala Kecil di Pekalongan Jawa Tengah, Jurnal Fakultas Perikanan dan Ilmu Kelautan IPB, Vol. 3 No. 1, 2012.

Soekartawi, Faktor Produksi Dalam Menghasilkan Barang dan Jasa. Jakarta: PT. Bumi Aksara, 2002.

Soekartawi, Faktor-faktor Produksi. Jakarta, Salemba Empat.

Sugiyono, 2012. Metode Penelitian Kombnasi.Bandung: Alfa Beta.

Sukirno, Sadono, 2009. Ekonomi Pembangunan, Proses, Masalah, dan Dasar Kebijaksanaan. Jakarta: Bina Grafika

Yofratha Jehau, Handrianus, 2009. Analisis Tekhnik, Biologis, dan Ekonomi Pengembangan Usaha Perikanan Purse Seine Di Kecamatan Galesong Utara Kabupaten Takalar. Skripsi Universitas Hasanuddin.

Yusuf Agunggunanto, Edy, 2011. Analisis Kemiskinan dan Pendapatan Keluarga Nelayan Kasus Di Kecamatan Wedung Kabupaten Demak, Jawa Tengah, Indonesia. Jurnal Fakulatas Ekonomi dan Bisnis Universitas Diponegoro Semarang. 